\title{
UPAYA PENINGKATAN KEMAMPUAN GURU UNTUK MENGGUNAKAN MEDIA PEMBELAJARAN DALAM PROSES PEMBELAJARAN MELALUI SUPERVISI AKADEMIK KEPALA SEKOLAH SD NEGERI 63 PEKANBARU
}

(Teacher Ability Improvement Efforts to Use Learning Media in Learning Process Through Academic Supervision Of School Heads of SD Negeri 63 Pekanbaru)

\author{
Oleh: Asnawati ${ }^{*}$ \\ HP :082169508515
}

*) Kepala Sekolah SD Negeri 63 Pekanbaru

\begin{abstract}
This study aims to help improve the competency of 63 Pekanbaru Elementary School teachers in the field of operating media in the learning process so that students are able to achieve minimum completeness criteria. As the subject in this study, elementary school teachers were horrified by 63 new sensitivities, totaling 13 people. The formulation of the problem in research $I$ is whether the ability to use instructional media by teachers of SD 63 Pekanbaru can be improved through the academic supervision of the principal ?. The technique of data collection is done by filling in the observation sheet during the research action process by the supervisor so that qualitative data will be obtained as a result of research with performance indicators said to be successful if the average score is $\geq 75$. The results of the study in cycle 1 obtained a percentage with a percentage score of $73 \%$ with a fairly good classification in the classification range (71-80). In the second cycle the percentage of success was obtained with a percentage score of $85 \%$ with a good classification in the classification range (81-90). Reflections on cycle 2 activities were successful because 85 were above the performance indicator> 75. The increase in understanding of the use of learning media from cycle I to cycle II. Weaknesses in the first cycle after being corrected in cycle II and reached a perfect level so that it can improve satisfactory results with good classification. Thus through academic supervision by the principal can improve the ability of teachers in understanding and using learning media in the SDN 063 Pekanbaru school "accepted".
\end{abstract}

Keywords: Learning Media, Academic Supervision of Principals. 


\section{PENDAHULUAN}

Media pembelajaran merupakan bagian penting dalam pelaksanaan pendidikan di sekolah, akan tetapi penyediaan media pembelajaran selama ini masih menjadi kendala atau problematika. Media pembelajaran merupakan sarana yang dipergunakan atau dimanfaatkan agar pengajaran dapat berlangsung dengan baik, memperdekat atau memperlancar jalan ke arah tujuan yang telah direncanakan.

Manfaat dari setiap media pembelajaran bergantung pada kemauan dan kemampuan guru dan peserta didik untuk berkomunikasi dan berinteraksi dengan pesan-pesan yang terkandung dalam media pembelajaran yang didayagunakan. Berbagai penelitian yang dilakukan terhadap pemanfaatan media dalam pembelajaran menunjukkan bahwa media tersebut berdampak positif dalam pembelajaran. "Sebuah gambar lebih berarti dari seribukata" seperti dituliskan oleh Deporter, Reardon, dan Singer Nourie bahwa penggunaan alat peraga ini dalam mengawali proses belajar akan merangsang moralitas visual dan menyalakan jalur syaraf sehingga memunculkan beribu-ribu asosiasi dalam kesadaran siswa. "Rangsangan visual dan asosiasi ini akan memberikan suasana yang sangat kaya untuk pembelajaran." (Marisa, dkk: 2012). Media pembelajaran berupa alat peraga menjadi sangat penting untuk mendukung konteksnya nyata dengan masyarakat.Dalam pembelajaran dengan konteksnya kebutuhan umat (masyarakat) perlu dihadirkan peraga-peraga praktis ke hadapan siswa.

Bagi siswa, seringkali materi yang bersifat terlalu abstrak membuat mereka bingung, untuk itu guru perlu membuat media pembelajaran sendiri sebagai pedoman bagi para siswanya yang dikembangkan sesuai karakteristik lingkungan sosial, budaya, dan geografis, juga mencakup tahapan perkembangan siswa, kemampuan awal yang telah dikuasai, minat, latar belakang keluarga dan lain-lain. Untuk itu, maka media pembelajaran yang dikembangkan sendiri dapat disesuaikan dengan karakteristik siswa sebagai sasaran. Ada sebagian guru yang hanya terpaku kepada bantuan dalam menyediakan media pembelajaran padahal media pembelajaran dapat didesain dari berbagai sumber dalam berbagai bentuk sesuai dengan kebutuhan dan karakteristik materi ajar yang akan disajikan. Melalui media pembelajaran guru akan lebih mudah dalam melaksanakan pembelajaran dan siswa akan lebih terbantu dan mudah dalam belajar. Apabila media pembelajaran yang sesuai dengan tuntutan kurikulum tidak ada satupun sulit diperoleh, maka membuat media pembelajaran sendiri adalah suatu keputusan yang bijak. Untuk mengembangkan media pembelajaran, referensi dapat diperoleh dari berbagai sumber baik itu berupa pengalaman ataupun pengetahuan sendiri, ataupun penggalian informasi dari nara sumber baik ahli ataupun teman sejawat. Akan tetapi hal tersebut merupakan suatu problem karena guru menganggap itu sangat sulit.

Dari paparan di atas dapat disimpulkan bahwa penggunaan media pembelajaran dalam proses pembelajaran menjadi hal yang mutlak dan tidak dapat diabaikan. Ironisnya, hal tersebut kurang mendapat perhatian dari guru, karena itu dianggap problem atau menambah pekerjaan terutama dengan menciptakan media pembelajaran yang cocok dan mendukung terhadap pembelajaran yang dilaksanakan.

Ada beberapa indikasi terhadap kondisi demikian, yang menyimpulkan kepada kurangnya kreatifitas guru dalam mempersiapkan media pembelajaran. Guru cenderung statis dalam mengembangkan media pembelajaran sesuai dengan materi yang diberikan. Di samping itu kadang kala media pembelajaran tidak sesuai dengan materi pelajaran yang diberikan guru. Dalam hal itu, tidak semua media pembelajaran cocok digunakan.

Adanya sumber anggaran operasional pendidikan (Bantuan Operasional Sekolah/“BOS") yang memungkinkan untuk pengadaan media pembelajaran, sekolah biasanya menganggarkan untuk alat media pembelajaran yang dimaksudkan sesuai dengan kebutuhan, sehingga guru tidak dituntut untuk mencari alternatif sendiri untuk 
mempersiapkan dan mengembangkan media pembelajaran sesuai pembelajaran yang dilaksanakan akan berkualitas, demi mencapai tujuannya. Atas dasar ini, tidak ada suatu upaya yang kreatif dari guru untuk mengadakan sendiri media pembelajaran dalam berbagai bentuk, hanya mengharapkan dari dana yang ada dan tidak kreatif sehingga media pembelajaran dari tahun ke tahun yang tersedia sangat terbatas sehingga proses belajar mengajar berjalan begitu saja tanpa ada perubahan mengikuti zaman. Pengembangan media yang dilakukan oleh guru masih sangat kurang maksimal. Karena pada umumnya guru hanya menggunakan media sederhana seperti buku paket dan gambar. Untuk penggunaan media yang lebih kreatif masih belum ada. Hal ini disebabkan oleh kemampuan guru dalam menggunakan media masih kurang. Dan ketersediaan media di sekolah untuk suatu pembelajaran kurang mencukupi.

Ada beberapa faktor yang menyebabkan guru SD Negeri 63 Pekanbarukesulitan dalam menggunakan media dalam proses pembelajaran di kelas, diantaranya: 1) Guru tidak memiliki kesadaran untuk maju berkompetisi mengikuti perkembangan dunia pendidikan, dalam mengajar guru masih menggunakan pola lama CBSA (catat buku sampai habis). 2) Guru belum pernah mengikuti pelatihan dalam mengoperasikan media pembelajaran dalam proses pembelajaran. 3) Guru sudah pernah mengikuti pelatihan, tapi belum mampu menerapkannya di sekolah. 4) Guru belum memiliki kesadaran untuk memanfaatkan media pembelajaran di sekolah meskipun sekolah sudah memfasilitasi perangkat media namun jarang dimanfaatkan. 5) Guru belum mengetahui manfaat media dapat memudahkan guru dalam proses pembelajaran. Siswa dapat lebih mudah memahami materi melalui media.

Kondisi tersebut tentu tidak bisa dibiarkan terus menerus, tetapi harus ada solusi dan tindakan nyata dari kepala sekolah sebagai penanggungjawab keberhasilan pendidikan di sekolahnya. Para guru tersebut harus mendapatkan pembinaan agar mampu meningkatkan kemampuannya dalam mengoperasikan media, khususnya media yang menggunakan teknologi modern seperti OHP, dll.Kepala sekolah perlu melakukan suatu tindakan melalui supervisi akademik untuk membantu meningkatkan kemampuan mereka dalam menyelesaikan permasalahan yang dihadapinya. Oleh sebab itu penulis tertarik untuk mengangkat judul "Upaya Peningkatan KemampuanGuru Untuk Menggunakan Media PembelajaranDalam Proses Pembelajaran Melalui Supervisi Akademik Kepala SekolahSD Negeri 63 Pekanbaru”. dengan Rumusan masalah dalam penelitian ini adalah "Apakah kemampuan menggunakan media pembelajaran oleh guru SD Negeri 63 Pekanbaru dapat ditingkatkan melalui supervisi akademik kepala sekolah?"Adapun yang manjadi tujuan dalam penelitian ini adalah untuk membantu meningkatkan kompetensi guru dibidang mengoperasikan media dalam proses pembelajaran sehingga peserta didik mampu mencapai kriteria ketuntasan minimal.

\section{Kompetensi dan Profesionalisme Guru}

Esensi sebuah pendidikan persekolahan adalah proses pembelajaran. Tidak ada kualitas pendidikan persekolahan tanpa kualitas pembelajaran. Berbagai upaya peningkatan mutu pendidikan persekolahan dapat dianggap kurang berguna bilamana belum menyentuh perbaikan proses pembelajaran. Oleh karena itu dalam rangka peningkatan kualitas pendidikan persekolahan Pemerintah,dalam hal ini Depatemen Pendidikan Nasional, mengembangkan berbagai program yang diharapkan dapat meningkatkan kualitas pembelajaran. Di antara keseluruhan komponen dalam pembelajaran guru merupakan komponen organik yang sangat menentukan. Tidak ada kualitas pembelajaran tanpa kualitas guru. Apapun yang telah dilakukan oleh Pemerintah, namun yang pasti adalah peningkatan kualitas pembelajaran tidak mungkin ada tanpa kualitas kinerja guru,sehingga peningkatan kualitas pembelajaran, juga tidaklah mungkin ada tanpa peningkatan kualitas para gurunya. Guru merupakan sumber daya manusia yang sangat menentukan keberhasilan pembelajaran. Guru merupakan unsur pendidikan yang sangat dekat hubungannya dengan anak didik dalam 
upaya pendidikan sehari-hari di sekolah dan banyak menentukan keberhasilan anak didik dalam mencapai tujuan. Undang-Undang Nomor 14 Tahun 2005 Tentang Guru dan Dosen, menyebutkan ada empat kompetensi yang harus dimiliki oleh seorang guru, yaitu kompetensi-kompetensi kepribadian, pedagogik, professional, dan sosial.

Para pakar pendidikan telah banyak menegaskan bahwa seseorang akan bekerja secara profesional apabila ia memiliki kompetensi yang memadai. Maksudnya adalah seseorang akan bekerja secara profesional apabila ia memiliki kompetensi secara utuh. Seseorang tidak akan bisa bekerja secara profesional apabila ia hanya memenuhi salah satu kompetensi di antara sekian kompetensi yang dipersyaratkan. Kompetensi tersebut merupakan perpaduan antara kemampuan dan motivasi. Betapapun tingginya kemampuan seseorang, ia tidak akan bekerja secara profesional apabila ia tidak memiliki motivasi kerja yang tinggi dalam mengerjakan tugas-tugasnya.Sebaliknya, betapapun tingginya motivasi kerja seseorang,ia tidak akan bekerja secara profesional apabila ia tidak memiliki kemampuan yang tinggi dalam mengerjakan tugas-tugasnya. Selaras dengan penjelasan ini adalah satu teori yang dikemukakan oleh Glickman (1981). Menurutnya ada empat prototipe guru dalam mengelola proses pembelajaran. Prototipe guru yang terbaik,menurut teori ini, adalah guru prototipe profesional. Seorang guru bisa diklasifikasikan ke dalam prototipe profesional apabila ia memiliki kemampuan tinggi (high level of abstract) dan motivasi kerja tinggi (high level of commitment). Di dalam Peraturan Menteri Pendidikan Nasional (Permendiknas) Nomor 16 Tahun 2007 tentang Standar Kualifikasi Akademik dan Kompetensi Guru ditegaskan bahwa setiap guru wajib memenuhi standar kualifikasi akademik dan kompetensi guru yang berlaku secara nasional. Kompetensi guru meliputi kemampuan, kompetensi kepribadian, kompetensi sosial, dan kompetensi professional.Di dalam permendiknas tersebut dirinci kompetensi inti guru dan kompetensi guru dalam mata pelajaran. Dalam kemampuan, disebutkan beberapa kompetensi inti yang harus dikuasai oleh seorang guru mata pelajaran, diantaranya sebagai berikut:

1. Mengembangkan kurikulum yang terkait dengan mata pelajaran yang diampu : memahami prinsip-prinsip pengembangan kurikulum, menentukan tujuan pembelajaran yang diampu, menentukan pengalaman belajar yang sesuai untuk mencapai tujuan pembelajaran yang diampu, memilih materi pembelajaran yang diampu yang terkait dengan pengalaman belajar dan tujuan pembelajaran, menata materi pembelajaran secara benar sesuai dengan pendekatan yang dipilih dan karakteristik peserta didik. mengembangkan indikator dan instrumen penilaian.

2. Menyelenggarakan pembelajaran yang mendidik : memahami prinsip-prinsip perancangan pembelajaran yangmendidik, mengembangkan komponenkomponen rancangan pembelajaran, menyusun rancangan pembelajaran yang lengkap, baik untuk kegiatan di dalam kelas,laboratorium, maupun lapangan.

\section{Pengertian Media Pembelajaran}

Kata media berasal dari bahasa latin medius yang secara harfiah berarti 'tengah', 'perantara', atau 'pengantar'. Secara lebih khusus, pengertian media dalam proses belajar mengajar cenderung diartikan sebagai alat-alat grafis, photografis, atau elektronik untuk menangkap, memproses, dan menyusun kembali informasi visual atau verbal. AECT (Association of Education andCommunication Technology) memberi batasan tentang media sebagai segalabentuk dan saluran yang digunakan untuk menyampaikan pesan atau informasi. Disamping sebagai sistem penyampai atau pengantar, media yang sering diganti dengan kata mediator, dengan istilah mediator media menunjukkan fungsi atau perannya, yaitu mengatur hubungan yang efektif antara dua pihak utama dalam proses belajar, yaitu siswa dan isi pelajaran. Ringkasnya, media adalah alat yang menyampaikan atau mengantarkan pesanpesan pengajaran (Azhar Arsyad, 2010:3).

Pengertian media pembelajaran adalah paduan antara bahan dan alat atau perpaduan antara 
software dan hardware (Sadiman, dkk, 1996: 5). Media pembelajaran bisa dipahami sebagai media yang digunakan dalam proses dan tujuan pembelajaran. Pada hakikatnya proses pembelajaran juga merupakan komunikasi, maka media pembelajaran bisa dipahami sebagai media komunikasi yang digunakan dalam proses komunikasi tersebut, mediapembelajaran memiliki peranan penting sebagai sarana untuk menyalurkan pesan pembelajaran. Menurut Anderson (1987) yang dikutip Bambang Warsita (2008: 123). Media dapat dibagai dalam dua kategori, yaitu alat bantu pembelajaran (instructional aids) dan media pembelajaran (instructional media). Alat bantu pembelajaran atau alat untuk membantu guru (pendidik) dalam memperjelas materi (pesan) yang akan disampaikan. Oleh karena itu alat bantu pembelajaran disebut juga alat bantu mengajar (teaching aids). Misalnya OHP/OHT, film bingkai (slide) foto, peta, poster, grafik, flip chart, model benda sebenarnya dan sampai kepada lingkungan belajar yang dimanfaatkan untuk memperjelas materi pembelajaran.

\section{Fungsi dan manfaat media pembelajaran}

Humalik (1986) yang dikutip Azhar Arswad (2010:15), mengemukakan bahwa pemakaian media pembelajaran dalam proses belajar mengajar dapat membangkitkan keinginan dan minat yang baru, membangkitkan motivasi dan rangsangan kegiatan belajar dan membawa pengaruh-pengarug psikologis terhadap siswa. Penggunaan mediapembelajaran pada orientasi pembelajaran akan sangat membantu keaktifan proses pembelajaran dan menyampaian pesan dan isi pelajaran pada saat itu. Selain membangkitkan motivasi dan minat siswa, media pembelajaran juga dapat membantu siswa meningkatkan pemahaman, menyajikan data dengan menarik dan terpercaya. Maksudnya: bahwasanya media pembelajaran paling besar pengaruhnya bagi indera dan lebih dapat menjamin pemahaman, orang yang mendengarkan saja tidaklah sama tingkat pemahamannya dan lamanya bertahan apa yang dipahaminya dibandingkan dengan mereka yang melihat, atau melihat dan mendengarkannya. Selanjutnya menjelaskan betapa pentingnya media pemebelajaran karena media pemebelajaran membawa dan membangkitkan rasa senang dan gembira bagi murid-murid dan memperbaharui semangat mereka, membantu memantapkan pengetahuan pada benak para siswa serta menghidupkan pelajaran.

Levie \& Lentsz (1982) yang dikutip Hujair AH. Sanaky (2009: 6), mengemukakan empat fungsi media pembelajaran, khususnya media visual, yaitu: Fungsi Atensi, Fungsi Afektif, Fungsi Kognitif, Fungsi Kompensatoris. Fungsi atensi media visual merupakan inti, yaitu menarik dan mengarahkanperhatian siswa untuk berkonsentrasi kepada isi pelajaran yang berkaitan dengan makna visual yang ditampilkan atau menyertai teks materi pelajaran. Seringkali pada awal pelajaran peserta didik tidak tertarik dengan materi pelajaran atau mata kuliah yang tidak disenangi oleh mereka sehingga mereka tidak memperhatikan. Media visual yang diproyeksikan dapat menenangkan dan mengarahkan perhatian mereka kepada mata kuliah yang akan mereka terima. Dengan demikian, kemungkinan untuk memperoleh dan mengingat isi materi perkuliahan semakin besar.

Fungsi afektif media visual dapat terlihat dari tingkat kenikmatan peserta didik ketika belajar atau membaca teks yang bergambar. Gambar atau lambang visual dapat menggugah emosi dan sikap siswa. Misalnya informasi yang menyangkut masalah sosial atau ras. Fungsi kognitif media visual terlihat dari lambang visual atau gambar memperlancar pencapaian tujuan untuk memahami dan mengingat informasi atau pesan yang terkandung dalam gambar.

Fungsi kompensatoris media pembelajaran terlihat dari hasil penelitian bahwa media visual yang memberikan konteks untuk memahami teks membantu siswa yang lemah dalam membaca untuk mengorganisasikan informasi dalam teks dan mengingatnya kembali. Dengan kata lain, media pembelajaran berfungsi untuk mengakomodasikan siswa yang lemah dan lambat menerima dan memahami isi pelajaran yang disajikan dengan teks atau disajikan 
secara verbal.

\section{Macam-macam Media Pembelajaran}

Media pembelajaran banyak sekali jenis dan macamnya. Beberapa media yang paling akrab dan hampir semua sekolah memanfaatkan adalah media cetak (buku) dan papan tulis. Selain itu, banyak juga sekolah yang telah memanfaatkan jenis media lain seperti gambar, model, overheadprojektor (OHP) dan obyek obyek nyata. Sedangkan media lain seperti kasetaudio, video, VCD, slide (film bingkai), serta program pembelajaran komputer masih jarang digunakan meskipun sebenarnya sudah tidak asing lagi bagi sebagian besar guru. Meskipun demikian, sebagai seorang guru alangkah baiknya Anda mengenal beberapa jenis media pembelajaran tersebut. Hal ini dimaksudkan agar mendorong kita untuk mengadakan dan memanfaatkan media tersebut dalam kegiatan pembelajaran di kelas.

Ada berbagai cara dan sudut pandang untuk menggolongkan jenis media. Rudy Bretz (1971) yang dikutip Sadiman, dkk (1996: 20), mengidentifikasi jenis jenis media berdasarkan tiga unsur pokok yaitu: suara, visual dan gerak. Berdasarkan tiga unsur tersebut, Bretz mengklasifikasikan media ke dalam delapan kelompok, yaitu: 1) media audio, 2) media cetak, 3) media visual diam, 4) media visual gerak, 5) media audio semi gerak, 6) media semi gerak, 7) media audio visual diam, 8) media audio visual gerak.

Sebagian ahli lain mengelompokkan media berdasarkan pada tingkat teknologi yang digunakan, mulai dari media dengan teknologi rendah hingga yang menggunakan teknologi tinggi. Jika media digolongkan atas dasar tingkat teknologi yang digunakan, maka penggolongan media sangat dipengaruhi oleh perkembangan teknologi. Media tertentu akan dapatmengalami perubahan dalam penggolongannya. Misalnya, pada tahun 1950-an, media televisi dikategorikan media paling tinggi. Tetapi kemudian pada tahun 1970-an kategori tersebut bergeser dengan hadirnya media komputer. Pada masa tersebut, komputer digolongkan pada media dengan teknologi yang paling tinggi. Beberapa pengelompokkan media dapat dilihat sampai saat ini belum ada suatu pengelompokkan media yang mencakup segala aspek, khususnya untuk keperluan pembelajaran. Pengelompokkan yang ada, dilakukan atas bermacam-macam kepentingan. Masih ada pengelompokkan yang dibuat oleh ahli lain, namun apapun dasar yang digunakan dalam pengelompokan itu, tujuannya sama yaitu agar orang lebih mudah mempelajarinya. Sebagai seorang guru, perlu mengikuti perkembangan teknologi khususnya yang berkaitan dengan media pembelajaran. Sehingga paling tidak kita dapat lebih mengenalnya. Beberapa jenis media tentu pernah Anda gunakan, beberapa jenis yang lain mungkin juga sudah Anda kenal meskipun belum pernah menggunakannya dalam pembelajaran. Jenis media mana yang akan kita gunakan, sangat tergantung pada kebutuhan dan kondisi yang ada di lapangan.

\section{Media Visual}

Setiap jenis media, mempunyai karakteristik (kekhasan) tertentu, yang berbeda beda satu sama lain. Masing-masing media tentu memiliki kelebihan dan kelemahan. Tidak semua jenis media yang disebutkan di atas akan dibahas di sini. Untuk mempermudah pembahasan karena pertimbanganpraktis, maka jenis media yang akan dibahas di sini hanya dipilih beberapa media yang biasa digunakan dalam pembelajaran. a. Media yang tidak diproyeksikan, Pengertian media pandang yang tidak diproyeksikan ialah bahwa media yang digunakan itu tidak membutuhkan suatu alat bantu lain (misalnya suatu proyektor) untuk melihatnya. Media seperti ini sangat banyak, mudah diperoleh, dan mudah digunakan secara luas dikelas bila dibanding dengan media pandang yang lain. Media seperti ini sangat umum dan banyak terdapat dalam lingkungan kehidupan kita, sehingga para pendidik/guru kadangkadang cenderung tidak memperhitungkan kehadiran media ini dalam proses pembelajaran. Padahal media ini selain mudah diperoleh, juga tidak membutuhkan peralatan yang rumit, tidak membutuhkan adanya aliran listrik, dan tidak membutuhkan tenaga khusus untuk melayaninya. Media seperti ini dapat digunakan dimana-mana, misalnya daerah-daerah yang 
belum terjangkau listrik dan sarana/prasarana komunikasi yang lancar (John D Latuheru, 1988: 41).

Kelompok media ini sering disebut sebagai media pameran (displayedmedia). Jenis media yang tidak diproyeksikan antara lain: realia, model, dangrafis. Ketiga jenis media ini dapat dikategorikan sebagai media sederhana yang penyajiannya tidak memerlukan tenaga listrik. Walaupun demikian media ini sangat penting bagi siswa karena mampu menciptakan kegiatan pembelajaran menjadi lebih hidup dan lebih menarik yaitu: Media realia adalah benda nyata yang digunakan sebagai bahan atau sumber belajar. Pemanfaatan media realia tidak harus dihadirkan secara nyata dalam ruang kelas, melainkan dapat juga dengan cara mengajak siswa melihat langsung (observasi) benda nyata tersebut ke lokasinya. Realia dapat digunakan dalam kegiatan belajar dalam bentuk sebagaimana adanya, tidak perlu dimodifikasi, tidak ada pengubahan kecuali dipindahkan dari kondisi lingkungan aslinya.

Ciri media realia yang asli adalah benda yang masih dalam keadaan utuh, dapat dioperasikan, hidup, dalam ukuran yang sebenarnya, dan dapat dikenali sebagai wujud aslinya. Media realia sangat bermanfaat terutama bagi siswa yang tidak memiliki pengalaman terhadap benda tertentu. Misalnya untuk mempelajari binatang langka, siswa diajak melihat badak yang ada di kebun binatang. Selain observasi dalam kondisi aslinya, penggunaan media realia juga dapat dimodifikasi. Modifikasi media realia berupa: potongan benda (cutaways), benda contoh (specimen), dan pameran (exhibid). Cara potongan (cutaways) adalah benda sebenarnya tidak digunakan secara utuh atau menyeluruh, tetapi hanya diambil sebagian saja yang dianggap penting dan dapat mewakili aslinya. Misalnya binatang langka hanya diambil bagian kepalanya saja. Benda contoh (specimen) adalah benda asli tanpa dikurangi sedikitpun yang dipakai sebagai contoh untuk mewakili karakter dari sebuah benda dalam jenis atau kelompok tertentu. Misalnya beberapa ekor ikan hias dari jenis tertentu, yang dimasukkan dalam sebuah toples berisi air untuk diamati di dalam kelas. Pameran (exhibit) menampilkan benda benda tertentu yang dirancang seolah olah berada dalam lingkungan atau situasi aslinya. Misalnya senjata senjata kuno yang masih asli ditata dan dipajang seolah-olah mengambarkan situasi perang pada jaman dulu.

Secara teori, penggunaan media realia ini banyak kelebihannya, misalnya dapat memberikan pengalaman nyata kepada siswa. Namun dalam prakteknya banyak bendabenda nyata yang tidak mudah dihadirkan dalam bentuk yang sebenarnya yang disebabkan oleh keterbatasan keterbatasan tertentu. Oleh karena itu perlu ada jenis media lain sebagai penggantinya, seperti dijelaskan berikut ini, Media model diartikan sebagai benda tiruan dalam wujud tiga dimensi yang merupakan representasi atau pengganti dari benda yang sesungguhnya. Penggunaan model sebagai media dalam pembelajaran dimaksudkan untuk mengatasi kendala tertentu untuk pengadaan realia. Model suatu benda dapat dibuat dengan ukuran yang lebih besar, lebih kecil atau sama dengan benda sesungguhnya. Model juga bisa dibuat dalam wujud yang lengkap seperti aslinya, bisa juga lebih disederhanakan hanya menampilkan bagian/ciri yang penting. Contoh model adalah: candi borobudur, pesawat terbang atau tugu monas yang dibuat dalam bentuk mini.

Media grafis tergolong jenis media visual yang menyalurkan pesan lewat simbol-simbol visual. Grafis juga berfungsi untuk menarik perhatian, memperjelas sajian pelajaran, dan mengilustrasikan suatu fakta atau konsep yang mudah terlupakan jika hanya dijelaskan melalui penjelasan verbal saja. Banyak konsep yang justru lebih mudah dijelaskan melalui gambar daripada menggunakan kata-kata verbal. Ingat ungkapan "Satu gambar berbicaraseribu kata". Semua media grafis, baik itu berupa gambar, sketsa bagan, grafik atau media visual yang lain harus dibuat dengan memperhatikan prinsip-prinsip umum. Sebagai salah satu media visual, grafis harus diusahakan memenuhi ketentuan ketentuan agar menghasilkan visual yang komunikatif. Untuk lebih mudah diingat, ketentuan tersebut dinyatakan dalam akronim "VISUALS" (singkatan dari Visible, Interesting, Simple, 
Useful,Accurate, Ligitimate, dan Structured). Secara singkat prinsip umumpembuatan visual itu dapat dijelaskan sebagai berikut. Visible berarti mudah dilihat oleh seluruh sasaran didik yang akan memanfaatkan media yang kita buat. Interesting artinya menarik, tidak monoton dan tidak membosankan. Simple artinya sederhana, singkat, dan tidak berlebihan. Useful maksudnyaadalah visual yang ditampilkan harus dipilih yang benar-benar bermanfaat bagi sasaran didik. Jangan menayangkan tulisan terlalu banyak yang sebenarnya kurang penting. Accurate artinya isi materi harus benar dan tepat sasaran. Jika pesan yang dikemas dalam media visual salah, maka dampak buruknya akan sulit terhapus dari ingatan siswa. Legitimate adalah visual yang ditampilkan harus sesuatu yang sah dan masuk akal. Visual yang tidak logis atau tidak lazim akan dianggap janggal oleh anak. Structured maksudnya visual harus terstruktur atau tersusun dengan baik, sistematis, dan runtut sehingga mudah dipahami pesannya. Media grafis banyak jenisnya, misalnya: gambar/foto, sketsa, bagan, diagram, grafik, poster, kartun dan sebagainya.

Gambar/foto adalah media yang paling umum dipakai dalam pembelajaran. Gambar/foto sifatnya universal, mudah dimengerti, dan tidak terikat oleh keterbatasan bahasa. Beberapa kelebihan media gambar/foto antara lain 1) sifatnya konkrit, 2) dapat mengatasi batasan ruang, waktu dan indera, 3) harganya relatif murah serta mudah dibuat dan digunakan dalam pembelajaran di kelas. Selain kelebihan, gambar/foto juga memiliki kelemahan, antara lain: 1) hanya menekankan pada persepsi indera mata, ukurannya terbatas hanya dapat terlihat oleh sekelompok siswa, 2) jika gambar terlalu kompleks, akan kurang efektif untuk tujuan pembelajaran tertentu.

Sketsa adalah gambar yang sederhana atau draft kasar yang melukiskan bagian bagian pokoknya tanpa detail. Selain dapat menarik perhatian siswa, sketsa dapat menghindarkan verbalisme dan memperjelas pesan. Sketsa dapatdibuat langsung oleh guru, karena itu harganya pasti murah (bahkan bisa tanpa biaya). Satu-satunya hambatan yang sering dikemukakan adalah guru tidak bisa menggambar. Padahal setiap orang pasti memiliki kemampuan dasar mengganbar, dan itu sudah cukup sebagai modal membuat sketsa untuk memperjelas sajian kita.

Diagram/skema merupakan suatu gambar sederhana yang menggunakan garis-garis dan simbol-simbol. Diagram menggambarkan struktur dari obyek tertentu secara garis besar, diagram menunjukkan hubungan yang ada antara komponennya atau sifat-sifat proses yang ada disana. Isi diagram pada umumnya berupa petunjuk untuk memahami komponen dan mekanisme kerja peralatan tertentu. Misalnya kalau kita membeli peralatan elektronik, biasanya disertai sebuah diagram mengenai komponen alat tersebut, fungsi, dan cara pengoperasian. Jika digunakan dalam pembelajaran, diagram bisa menyederhanakan sesuatu yang kompleks sehingga dapat membantu memperjelas penyajian guru. Kelebihannya diagram dapat menyajikan materi yang luas dan kompleks menjadi lebih padat dan sederhana. Namun untuk bisa memahami diagram, siswa harus memiliki latar belakang tentang materi yang didiagramkan. Diagram yang baik haruslah: 1) benar datanya, 2) rapi, 3) diberi judul dan penjelasan seperlunya, 4) ukurannya cukup dan dapat dilihat oleh siswa dalam jumlah yang diinginkan, 5) penyusunannya disesuaikan dengan pola membaca yang umum (dari kiri ke kanan).

Bagan/chart. Fungsi bagan/chart yang pokok adalah menyajikan ide-ide atau konsep yang sulit sehingga lebih mudah dicerna siswa. Bagan mampumemberikan ringkasan butir-butir penting dari suatu penyajian. Dalam bagan/chart sering dijumpai bentuk grafis yang lain seperti: gambar, diagram, kartun atau lambang verbal. Agar menjadi media yang baik, bagan hendaknya dibuat: 1) secara sederhana, 2) lugas, 3) tidak berbelit belit, dan 4) up to date.

Grafik merupakan gambar sederhana yang menggunakan garis, titik, simbol verbal atau bentuk tertentu yang menggambarkan data kuantitatif. Grafik digunakan untuk 
menjelaskan perkembangan atau perbandingan suatu obyek yang saling berhubungan. Grafik biasanya disusun berdasarkan prinsip matematika dan menggunakan data komparatif. Ada beberapa bentuk grafik, antara lain: grafik garis, grafik batang, grafik lingkaran, dan grafik gambar.

Semakin rumit data yang akan disajikan akan semakin efektif bila disajikan melalui grafik. Grafik yang baik haruslah: 1) jelas untuk dilihat dan dibaca siswa, 2) hanya menyajikan satu ide/pokok masalah, 3) menggunakan warna-warna kontras dan harmonis, 4) dibuat secara ringkas dan diberikan judul, 5) sederhana, menarik, teliti dan mampu "berbicara sendiri" (begitu siswa membaca, langsung mengerti maksudnya).

\section{Pembinaan Guru melalui Supervisi Akademik Kepala Sekolah}

Salah satu program yang dapat diselenggarakan dalam rangka pemberdayaan guru adalah supervisi akademik (supervisi akademik).Supervisi akademik adalah serangkaian kegiatan membantu guru mengembangkan kemampuannya mengelola proses pembelajaran demi pencapaian tujuan akademik. Supervisi akademik merupakan upaya membantu guru-guru mengembangkan kemampuannya mencapai tujuan akademik.Dengan demikian, berarti, esensial supervisi akademik adalah membantu guru mengembangkan kemampuan profesionalismenya. Mengembangkan kemampuan dalam konteks ini janganlah ditafsirkan secara sempit, semata-mata ditekankan pada peningkatan pengetahuan dan keterampilan mengajar guru, melainkan juga pada peningkatan komitmen(commitmen) atau kemauan (willingness) atau motivasi (motivation) guru, sebab dengan meningkatkan kemampuan dan motivasi kerja guru, kualitas akademik akan meningkat. Di dalam Peraturan menteri Pendidikan Nasional (Permendiknas) Nomor 13 Tahun 2007 tentang Standar Kepala Sekolah ditegaskan bahwa salah satu kompetensi yang harus dimiliki seorang kepala sekolah adalah kompetensi supervisi. Dengan Permendiknas tersebut berarti seorang kepala sekolah harus kompeten dalam melakukan supervisi akademik terhadap guru-guru yang dipimpinnya Salah satu tugas Kepala Sekolah adalah melaksanakan supervisi akademik.Untuk melaksanakan supervisi akademik secara efektif diperlukan keterampilan konseptual, interpersonal dan teknikal (Glickman, at al; 2007).Oleh sebab itu, setiap Kepala Sekolah harus memiliki dan menguasai konsep supervisi akademik yang meliputi: pengertian, tujuan dan fungsi, prinsipprinsip,dan dimensi-dimensi substansi supervisi akademik.

\section{Konsep supervisi akademik}

Supervisi akademik adalah serangkaian kegiatan membantu guru mengembangkan kemampuannya mengelola proses pembelajaran untuk mencapai tujuan pembelajaran (Daresh, 1989, Glickman, et al; 2007). Supervisi akademik tidak terlepas dari penilaian kinerja guru dalam mengelola pembelajaran. Sergiovanni (1987) menegaskan bahwa refleksi praktis penilaian kinerja guru dalam supervisi akademik adalah melihat kondisi nyata kinerja guru untuk menjawab pertanyaan-pertanyaan,misalnya apa yang sebenarnya terjadi di dalam kelas?, apa yang sebenarnya dilakukan oleh guru dan siswa di dalam kelas?, aktivitas-aktivitas mana dari keseluruhan aktivitas di dalam kelas itu yang bermakna bagi guru dan murid?, apa yang telah dilakukan oleh guru dalam mencapai tujuan akademik?, apa kelebihan dan kekurangan guru dan bagaimana cara mengembangkannya?. Berdasarkan jawaban terhadap pertanyaan pertanyaan ini akan diperoleh informasi mengenai kemampuan guru dalam mengelola pembelajaran. Namun satu hal yang perlu ditegaskan di sini, bahwa setelah melakukan penilaian kinerja bukan berarti selesailah pelaksanaan supervisi akademik, melainkan harus dilanjutkan dengan tindak lanjutnya berupa pembuatan program supervisi akademik dan melaksanakannya dengan sebaik-baiknya.

\section{METODE PENELITIAN}

Penelitian ini dilakukan dalam tiga tahapan, yaitu persiapan, pelaksanaan dan evaluasi dan 
refleksi, dan dilakukan minimal dalam dua siklus. Pada tahap persiapan dibuat dibuat skenario kegiatan, jadwal waktu, tempat serta sarana pendukung lainnya seperti lembar observasi, serta angket.

\section{Lokasi dan Waktu penelitian}

Penelitian dilakukan di SD Negeri 63 Pekanbaru dimulai tanggal 7 agustus 2018 s/d 9 oktober 2018.

\section{Siklus 1}

\section{Perencanaan}

Penelitian tindakan ini melibatkan seluruh guru di SDN 063 pekanbaru yaitu sebanyak 13 orang guru.Hal ini perlu dilakukan karena mereka tidak pernah dibekali dengan pengetahuan tentang penggunaan media pembelajaran sehingga mengalami kesulitan untuk memanfaatkan media pembelajaran yang tersedia disekolah.Kegiatan ini dilakukan selama 2 bulan yaitu sejak bulan agustus sampai oktober 2018,dan dilakukan di sekolah dengan pengaturan waktu yang lebih fleksibel sehingga tidak mengganggu jadwal kegiatan pembelajaran. Sarana yang digunakan dalam kegiatan ini adalah media yang telah tersedia di sekolah seperti OHP, Laptop, alat peraga, globe, mikroskop dan peralatan labor lainnya..Kegiatan ini dilakukan dalam dua siklus hingga guru dinilai memiliki kemampuan untuk mengoperasikan media dengan mahir dan tidak gaptek sebagaimana sebelumnya..

\section{Tindakan dan pengamatan}

1) Penelitian diawali dengan cara meperkenalkan jenis media yang ada disekolah

2) Guru mempelajari cara penggunaan media tersebut dan fungsi serta mantaat dari media tersebut.

\section{Siklus 2}

Kegiatan Perencanaan berdasarkan pada refleksi dari siklus 1, sementara untuk langkahlangkah kegiatan tindakan dan pengamatan sama dengan siklus 1 dengan memperhatikan prioritas permasalahan yang disimpulkan pada siklus 1 dan dilanjutkan dengan kegiatan refleksi. Apabila hasil refleksi pada siklus 2 sudah menunjukan adanya Peningkatan Kemampuan guru secara signifikan, maka kegiatan penelitian dianggap berhasil, tetapi sebaliknya apabila belum menunjukan hasil yang di harapkan, maka kegiatan penelitian akan dilanjutkan dengan siklus berikutnya dengan langkah-langkah kegiatan yang sama dengan kegiatan pada siklus 2 ini.

\section{Teknik Pengumpulan Data}

Teknik pengumpulan data dilakukan dengan cara pengisian lembar observasi selama proses tindakan penelitian oleh supervisor sehingga akan diperoleh data kualitatif sebagai hasil penelitian.

\section{Indikator Kinerja}

Penelitian ini dikatakan berhasil apabila score rata-rata $\geq 75$.

\section{Instrumen Penelitian}

Instrumen penelitian yang digunakan adalah lembar observasi yang digunakan oleh supervisor untuk mencatat perkembangan kemampuan masing masing guru yang dibinanya selama proses penelitian( siklus 1 dan siklus 2).

\section{Teknik Analisis Data}

Untuk mengetahui keberhasilan penelitian, digunakan analisa dengan rumus:

$$
\begin{gathered}
\mathrm{PK}=\frac{S T}{\mathrm{~N}} \times 100 \% \\
\text { Ket }: \quad \mathrm{PK}=\text { Persentase Keberhasilan } \\
\mathrm{ST}=\text { jumlah skor total } \\
\mathrm{N}=\text { Jumlah peserta }
\end{gathered}
$$




\section{Deskripsi Lokasi Penelitian}

Penelitian tindakan yang dilakukan di SD Negeri 63 Pekanbaru ini dilakukan oleh kepala sekolah melalui tehnik supervisi akademik secara berkelompok sebagai upaya untuk meningkatkan kemampuan/kemampuan guru dalam menyusun perencanaan pembelajaran di kelas. Penelitian dilakukan terhadap 13 orang guru SD Negeri 63 Pekanbaru. Namun demikian permasalahan dalam penelitian tindakan ini difokuskan pada penggunaan media pembelajaran dengan asumsi apabila guru sudah mampu menggunakan media pembelajaran dengan baik, maka hasil pembelajaran terhadap siswa akan baik pula.. Kegiatan yang dilakukan dalam 2 siklus ini, dilakukan sejak bulan agustus sampai bulan oktober 2018 dengan menitikberatkan pada unsur-unsur penggunaan media pembelajaran sebagaimana yang terlihat pada kegiatan tindakan penelitian yang telah diuraikan pada BAB III. Dari dari awal yang diperoleh pada kegiatan penelitian, terlihat dari 13 orang terdapat 9 guru atau69\% guru masih memiliki kesulitan untuk mengoperasikan media pembelajaran khususnya media yang berbasis komputer. Di bawah ini dapat kita lihat pada grafik kemampuan guru pada awal kegiatan :

Gambar 4.1 Grafik Kemampuan Menggunakan media pembelajaran

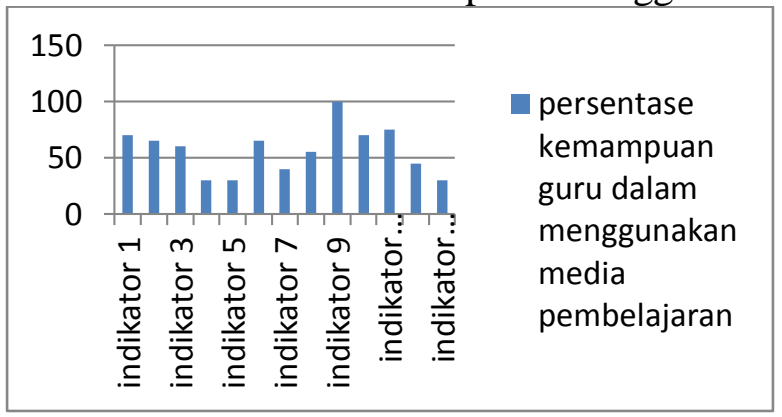

\section{Hasil Penelitian \\ Siklus 1 \\ Rencana}

Siklus 1 dilakukan pada tanggal 14 s/d 21 agustus 2018.Sebelum pelaksanaan tindakan terlebih dahulu kepala sekolah menyiapkan beberapa langkah persiapan refleksi seperti yang telah disajikan di Bab III. Dalam kegiatan tersebut peneliti dibantu oleh oeserver/teman sejawat kepala sekolah SD lain yaitu Ibu Nurhasanah, S.Pd. Peneliti meminta teman sejawat untuk menjadi observer dalam penelitian ini. Selanjutnya peneliti mempersiapkan lembar observasi terhadap kegiatan berlangsung.

\section{Tindakan}

Perbaikan upaya peningkatan kemampuan guru untuk menggunakan media pembelajaran melalui supervise akademik yang dilakukan oleh kepala sekolah terus diupayakan melalui pelatihan / pembekalan oleh tenaga ahli dalam bidang media pembelajaran sebagai kegiatan awal. Setelah pelatihan / pembekalan dilakukan guru kepala sekolah melakukan riset PTS untuk mengetahui seberapa berhasilkah pengetahuan yang diselap guru dari pelatihan tentang media pembelajaran. Setelah kegiatan awal dengan berbagai aktivitas yang dilakukan dan dilanjutkan dengan kegiatan inti. Peneliti memberikan lembar observasi penelitian kepada observer untuk menilai bagaimana implementasi penerapan media tersebut. Kegiatan diakhiri dengan mengevaluasi daya serap guru berkenaan dengan media pembelajaran.

\section{Pengamatan (Observation)}

Secara umum pada saat menjelaskan materi pelatihan media pembelajaran, guru terlihat sudah cukup mengusai dan mengoperasikan media. Berdasarkan hasil penelitian, diketahui rata-rata nilai peserta tertinggi terdapat pada indicator ke 9dengan skor89 yaitu Penggunaan buku teks dalam pembelajaran. Sementara rata-rata indicator terendah terdapat pada indicator 
1 yaitu penggunaan media realita dalam pembelajaran seperti ikan hias, benda-benda kuno, berkunjung ke kebun binatang atau museum.Untuk mengetahui keberhasilan penelitian pada siklus 1, digunakan analisa dengan rumus:

$$
\begin{aligned}
\mathrm{PK} & =\frac{S T}{\mathrm{~N}} \times 100 \% \\
\mathrm{PK} & =\frac{949}{13} \times 100 \% \\
\mathrm{PK} & =73 \%
\end{aligned}
$$

Setelah dilakukan analisis pada siklus 1 diperoleh persentase dengan skor persentase sebesar 73\% dengan klasifikasi cukup baik dalam rentang klasifikasi (71-80).Penelitian pada siklus 1 masuh belum berhasil karena 73 berada dibawah indicator kinerja yaitu $>75$. Melihat hasil yang diperoleh pada refleksi kegiatan siklus 1, maka dilakukan tindakan penelitian pada siklus 2 dengan menggunakan hasil tindakan siklus 1 sebagai bahan masukan dalam perencanaan kegiatan siklus ini dengan tujuan untuk lebih meningkatkan dan menguatkan kemampuan guru dalam menggunakan media pembelajaran hingga bisa mencapai hasil minimal $81 \%$ (baik).

\section{Siklus 2}

\section{Rencana}

Siklus 1 dilakukan pada tanggal 4 s/d 11 september 2018. Sebelum pelaksanaan tindakan terlebih dahulu kepala sekolah menyiapkan beberapa langkah persiapan refleksi seperti yang telah disajikan di Bab III. Selanjutnya peneliti mempersiapkan lembar observasi terhadap kegiatan berlangsung.

\section{Tindakan}

Sebagaimana pada siklus 1, perbaikan upaya peningkatan kemampuan guru untuk menggunakan media pembelajaran melalui supervisi akademik yang dilakukan oleh kepala sekolah terus diupayakan melalui pelatihan / pembekalan oleh tenaga ahli dalam bidang media pembelajaran sebagai kegiatan awal. Setelah pelatihan / pembekalan dilakukan guru kepala sekolah melakukan riset PTS untuk mengetahui seberapa berhasilkah pengetahuan yang diselap guru dari pelatihan tentang media pembelajaran. Setelah kegiatan awal dengan berbagai aktivitas yang dilakukan dan dilanjutkan dengan kegiatan inti. Peneliti memberikan lembar observasi penelitian kepada observer untuk menilai bagaimana implementasi penerapan media tersebut.Kegiatan diakhiri dengan mengevaluasi daya serap guru berkenaan dengan media pembelajaran.

\section{Pengamatan (Observation)}

Secara umum pada saat menjelaskan materi pelatihanmedia pembelajaran, guru terlihat sudah cukup mengusai dan mengoperasikan media. Berdasarkan hasil analisis data, diketahui ratarata nilai peserta tertinggi terdapat pada indicator ke 9 dengan skor 96 yaitu Penggunaan buku teks dalam pembelajaran. Sementara rata-rata indicator terendah terdapat pada indicator 1 yaitu penggunaan media realita dalam pembelajaran seperti ikan hias, benda-benda kuno, berkunjung ke kebun binatang atau museum dan indicator 5 yaitu pemahaman dalam membuat Slide melalui power point dengan skor 83. Untuk mengetahui keberhasilan penelitian pada siklus 1 , digunakan analisa dengan rumus:

$$
\begin{aligned}
& \mathrm{PK}=\frac{S T}{\mathrm{~N}} \times 100 \% \\
& \mathrm{PK}=\frac{1024}{13} \times 100 \% \\
& \mathrm{PK}=85 \%
\end{aligned}
$$

Setelah dilakukan analisis pada siklus 2 diperoleh persentase keberhasilan dengan skor persentase sebesar $85 \%$ dengan klasifikasi baik dalam rentang klasifikasi $(81-90)$.. Melihat 
hasil yang diperoleh pada refleksi kegiatan siklus 2, sudah dikatakan berhasil karena 85 berada diatas indicator kinerja $>75$.

\section{Pembahasan}

Dari hasil observasi pada siklus 1rata-rata skor keseluruhan peserta adalah 73 dikategorikan belum berhasil, karena masih dibawah indicator kinerja yaitu $>75$, sementara pada siklus 2 rata-rata skor keseluruhan peserta adalah 85 dengan klasifikasi baik. Pada siklus 2 ini penelitian dikatakan berhasi karena 85 berada diatas indicator kinerja. Keberhasilan pada siklus 2 ini disebabkan penguasaan media oleh peserta pada siklus I masih belum optimal seperti dijelaskan dalam siklus 2.

Berdasarkan pengamatan diketahui bahwa terjadinya peningkatan pemahaman penggunaan media pembelajaran dari siklus I ke siklus II. Kelemahan-kelemahan pada siklus I tersebut setelah diperbaiki pada siklus II dan mencapai tingkat sempurna sehingga dapat meningkatkan hasil yang memuaskan dengan klasifikasi baik.. perbandingan tersebut dapat digambarkan melalui gambar dibawah ini:

\section{Gambar IV.2}

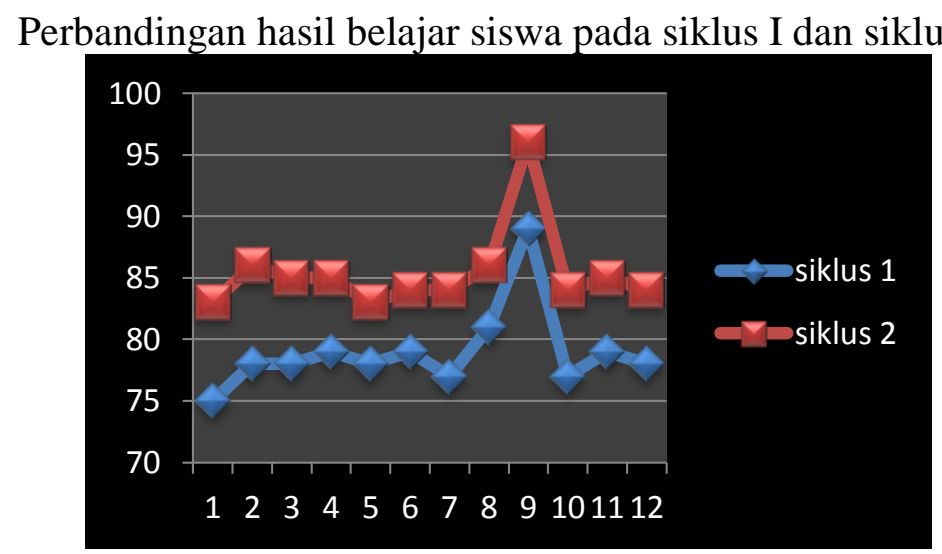

\section{Pengujian Hipotesis}

Berdasarkan hasil penelitian dan pembahasan seperti yang telah diuraikan di atas menjelaskan bahwa melalui supervise akademik oleh kepala sekolah dapat meningkatkan kemampuan guru dalam pemahaman dan penggunaan media pembelajaran di sekolah SDN 063 Pekanbaru “diterima”.

\section{Kesimpulan}

Problematika yang dihadapi guru dalam pengembangan media yaitu masih kurangnya keinginan guru dan kemampuan guru dalam menggunakan alat-alat media pembelajaran masih kurang. Upaya untuk mengatasi permasalahan tersebut dalam pengembangan media pembelajaran yaitu memanfaatkan semaksimal mungkin terhadap media pembelajaran yang ada dengan pembelajaran yang efektif dan menyenangkan, dilain sisi kepala sekolah mengusulkan pengadaan kelengkapan media pembelajaran kepada pihak dinas pendidikan danmembuat pelatihan-pelatihan kepada guru-guru tentang cara penggunaan media pembelajaran. Hasil penelitian melalui supervise akademik yang dilakukan oleh kepala sekolah SD Negeri 063 Pekanbaru dapat disimpulkan sebagai berikut:

1. Pada siklus 1 diperoleh persentase dengan skor persentase sebesar $73 \%$ dengan klasifikasi cukup baik dalam rentang klasifikasi (71-80). Penelitian pada siklus 1 masuh belum berhasil karena 73 berada dibawah indicator kinerja yaitu $>75$

2. Pada siklus 2 diperoleh persentase keberhasilan dengan skor persentase sebesar $85 \%$ dengan klasifikasi baik dalam rentang klasifikasi $(81-90)$.. Refleksi kegiatan siklus 2 dikatakan berhasil karena 85 berada diatas indicator kinerja $>75$. Terjadinya peningkatan pemahaman penggunaan media pembelajaran dari siklus I ke siklus II. Kelemahan-kelemahan pada siklus I tersebut setelah diperbaiki pada siklus II dan 
mencapai tingkat sempurna sehingga dapat meningkatkan hasil yang memuaskan dengan klasifikasi baik.

\section{Saran}

1. Kegiatan supervisi akademik sangat baik dilakukan untuk membina guru meningkatkan kompetensinya. Sebaiknya kegiatan ini dilaksanakan secara terencana dan berkesinambungan.

2. Sebaiknya pembinaan ini dilanjutkan dengan supervisi akademik dalam pelaksanaan pembelajaran untuk mengukur kemampuan guru dalam menerapkan penggunaan media pembelajaran dalam proses belajar mengajar.

3. Agar guru lebih optimal dalam memanfaatkan media yang telah disediakan oleh sekolah agar dapat membantu tercapainya tujuan pembelajaran.

\section{DAFTAR PUSTAKA}

Amal Abdussalam, Mengembangkan Kreativitas Anak, Jakarta: Pustaka Al-Kausar, 2005

Arief S. Sadiman, et. al, Media Pembelajaran, Jakarta: Departemen Pendidikan Nasional Direktorat Jenderal Pendidikan Dasar dan Menengah Direktorat Tenaga Kependidikan, 2003

Departemen Pendidikan dan Kebudayaan RI. 1982. Alat Penilaian Kemampuan Guru: Buku I. Jakarta: Proyek PengembanganPendidikan Guru.

1982. Panduan Umum Alat Penilaian Kemampuan Guru.Jakarta: Proyek Pengembangan Pendidikan Guru.

. Alat Penilaian Kemampuan Guru: Hubungan antar Pribadi.Buku III. Jakarta: Proyek Pengembangan Pendidikan Guru.

. Alat Penilaian Kemampuan Guru: Prosedur Mengajar. Buku II. Jakarta: Proyek

Pengembangan Pendidikan Guru.

Sadiman, Arif, dkk, Media Pendidikan, Pengertian, Pengembangan, danPemanfaatan, edisi Ketiga, cetakan ke-16, Jakarta: Raja GrafindoPersada, 2010

Sugiono, Metode Penelitian Pendiidkan; Pendekatan Kualitatif, Kuantitatif,dan R\&D, Bandung: Alfabeta, 2009

Suharsimi Arikunto, Manajemen Penelitian, cetVII, Jakarta: Rineke Cipta, 2005

Suhardjono, A. Azis Hoesein, dkk (1995). Pedoman penyusunan KTI di Bidang Pendidikan dan Angka Kredit Pengembangan Profesi Guru. Digutentis, Jakarta : Diknas

Suharsimi, Suhardjono dan Supardi. 2006. Penelitian Tindakan Kelas. Jakarta : PT Bumi Aksara

Supardi. 2005. Penyusunan Usulan, dan Laporan Penelitian Penelitian Tindakan Kelas, Makalah disampaikan pada "Diklat Pengembangan Profesi Widyaiswara", Ditektorat Tenaga Pendidik dan Kependidikan Dirjen Pendidikan Dasar dan Menengah, Departemen Pendidikan Nasional.

Wina Sanjaya, Perencanaan dan Desain Sistem Pembelajaran, Jakarta:Kencana Prenada Media Group, 2010 